Monk's Music 



\section{Monk's Music}

THELONIOUS MONK AND

JAZZ HISTORY IN THE MAKING

Gabriel Solis

甲

UNIVERSITY OF CALIFORNIA PRESS

BERKELEY LOS ANGELES LONDON 
University of California Press, one of the most distinguished university presses in the United States, enriches lives around the world by advancing scholarship in the humanities, social sciences, and natural sciences. Its activities are supported by the UC Press Foundation and by philanthropic contributions from individuals and institutions. For more information, visit www.ucpress.edu.

University of California Press

Berkeley and Los Angeles, California

University of California Press, Ltd.

London, England

(C) 2008 by The Regents of the University of California

An earlier version of chapter 2 appeared in The Musical Quarterly 86, no. I (Spring 2002): 82-II6, published by Oxford University Press, copyright (C) 2002 by Oxford University Press. Reprinted by permission.

Library of Congress Cataloging-in-Publication Data

Solis, Gabriel, 1972-.

Monk's music: Thelonious Monk and jazz history in the making / Gabriel Solis.

p. $\quad$ cm. - (Roth Family Foundation Music in

America imprint)

Includes bibliographical references and index.

ISBN 978-0-520-25200-4 (cloth : alk. paper)

ISBN 978-0-520-2520I-I (pbk. : alk. paper)

I. Monk, Thelonious-Criticism and interpretation. 2. Monk, Thelonious-Influence. 3. Jazz-History and criticism. I. Title.

ML417.M846S55 2008

$786.2165092-\mathrm{dc} 22$

2006102231

[B]

Manufactured in the United States of America

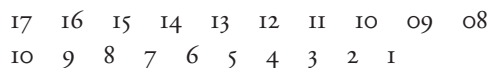

This book is printed on Cascades Enviro I00, a I00\% postconsumer-waste, recycled, de-inked fiber. FSC recycled certified and processed chlorine free. It is acid-free, Ecologo certified, and manufactured by BioGas energy. 
FOR ELLEN, COLEMAN, AND ISABELLA, WHO GIVE ME REASONS TO WORK AND REASONS TO PLAY 
